\title{
Anti-fertility Effects of Ethanolic Extract of Anethumgraveolens in Male Rabbits
}

\author{
Mariam A. Kadhem ${ }^{1}$, Ahlam A. Alrekabi², Huda K. Khassaf ${ }^{3}$ \\ ${ }^{1}$ Prof., Department of Physiology, Pharmacology and Chemical, College of Veterinary Medicine, University \\ of Basra, Basra, Iraq, ${ }^{2}$ Assist. Prof. Dr., Department of Physiology, Pharmacology and Chemical, College of \\ Veterinary Medicine, University of Basra, Basra, Iraq, ${ }^{3}$ Assist. Lecturer, Department of Physiology, Pharmacology \\ and Chemical, College of Veterinary Medicine, University of Basra, Basra, Iraq
}

\begin{abstract}
Gonadectomy is the most commonly utilized method for permanent contraception in small animals. But some negative side effects can be noticed after surgical castration, therefore finding safe and effective contraceptive substances can be so useful, medicinal plants have a long history of use in traditional medicine. The sperm cell count, motility, live/dead sperm cell ratio, morphology, LH, FSH and Testosterone level were used in this study to evaluate the effect of prolonged administration of ethanolic extract of Anethumgraveolens on male reproductive system in male rabbits. Twelve healthy adult male rabbit were randomly divided in to two groups. The rabbits in group 1 (control group) were administered normal saline $(3 \mathrm{ml})$, while rabbits in group 2 were administered ethanolic extract of Anethumgraveolens at dose $0.5 \mathrm{gm} . / \mathrm{kg} \mathrm{B}$.W for 30 days. The treatment with extract caused significant decrease in sperm motility, live/dead, sperm count, sperm LH, FSH and testosterone level with significant increase $(\mathrm{P} \leq 0.05)$ of abnormal sperm. Histological study showed many pathological changes in testes. On the other hand, Prolonged administration of the extract could be a good source of drug for birth control.
\end{abstract}

Keywords: Anethumgraveolens, sperm, testes, LH, FSH and testosterone, Rabbit.

\section{Introduction}

Gonadectomy is the very commonly used method for permanent contraception in small animals. But several negative side effects can be observed after surgical castration, therefore finding safe and effective contraceptive materials can be very useful, medicinal herbs have a long history of use in traditional medicine. Anethumgraveolens L commonly known as dill belonging to the family Umbelliferae, the generic name Anethum is derived from the Greek word anethon and the common name dill comes from the Norse word dylla or dilla which probably means to soothe ${ }^{1}$. Dill an annual herb growing in the Mediterranean region, Europe, central, southern Asia. The plant is used both medicinally and as an aromatic herb and spice and cookery. dill has been used traditionally for gastrointestinal ailments such as flatulence, indigestion, stomachache colic and to tract intestinal gas ${ }^{2}$ it is used anticonvulsant, antiemetic, anticramp (in children) remedy and also recommended topically as a wound healers ${ }^{3}$, antispasmodic ${ }^{4}$, antimicrobial $^{5}$, cardioprotective ${ }^{6}$, antihyperlipidemic ${ }^{7}$ and antiproliferative activity ${ }^{8}$ the aim of the present study is to evaluating the effect of ethanolic extract of Anethumgraveolens on fertility in male rabbits.

\section{Material and Method}

Collection of plant materials and extraction: Fresh plant of dill was purchased from the local market at Basra-Iraq. The shade dried plant was finely powdered in chemical mixer, $50 \mathrm{gm}$ of powder were put in the round bottle flask, $200 \mathrm{ml}$ of ethanol $(70 \%)$ were added to flask and extracted for 12 hours at $70^{\circ} \mathrm{C}$ the extract was filtered by using whatmann filter paper, then the extract were put in the petridish and left at room temperature under the shade, the collection extracts were kept in tight closed container and stored till using ${ }^{9}$.

Experimental Animals: Twelve healthy adult male rabbit weighting 1000-1500 gm. were used, the animals kept in suitable cages in the animal house of 
veterinary medicine college/Basra university, rabbits were acclimated to holding facilities for two weeks prior to the experiment and were fed standard diet and water ad libitum.

The animals were divided into two groups, each group containing 6 animals as follow:

Group 1: Rabbits received oral administration of normal saline $(3 \mathrm{ml})$ for 30 days (served as control group).

Group 2: Rabbits received oral administration of ethanolic extract of Anethumgraveolens at dose $0.5 \mathrm{gm} . /$ $\mathrm{kg} \mathrm{B.W}$ for 30 days.

Blood Samples: At the end of experimental period, blood samples were withdrawn from all animals through cardiac puncture, then the blood samples were put in a screw tube without anticoagulant then centrifuged at $5000 \mathrm{rpm}$ for 15 minutes to get serum for hormonal assay.

Hormonal Assay: Serum samples were assayed for testosterone, using the enzyme- linked immunosorbent assay (ELISA) technique using the Fortress kit.

The concentration of FSH and LH were measured by Enzyme Linked Immuno Assay (ELISA) technique according to kit (Monobind Inc. lake forest CA 92630 USA).

Semen Collection: The testes were removed along with the epididymis. The caudal epididymis were separated from the testes, blotted with filter papers and lacerated to collect the semen.

Semen Analysis: Progressive sperm motility: this was done immediately after the semen collection. Semen was squeezed from the caudal epididymis onto pre-warmed microscope slide $37^{\circ}$ and two drops of warm $2.9 \%$ sodium citrate was added, the slide was then covered with a warm cover slide and examined under the microscope. The percentage of motile sperms was defined as the number of motile sperms divided by the total number of counted sperms ${ }^{10}$.

Sperm Viability: Eosin and Negrosine stain was used to identify the live and dead sperms. The dead sperm stained with the eosin, while the live sperm did not. The stained and unstained sperms were counted and the percentages was calculate (11).
Viability $=$ No. of live sperm $/$ No. of sperm count $\times$ 100

Sperm abnormality: Sperm suspension $50 \mu 1$ was put on one end of the clean and warm slide, then a drop of Eosin-Negrosine stain was added, mixed by using glass rod and spreaded all over the slide by another slide. The smear was left to dry and examined under oil immersion. The abnormal sperms were calculated in each slide by examining 200 sperms ${ }^{12}$.

$\%$ Abnormal sperms $=$ No. of abnormal $/$ No. of total sperm x100

Sperm Count: This was done by removing the caudal epididymis from the right testes and blotted with filter paper. The caudal epididymis was immersed in $5 \mathrm{ml}$ formal-saline in a graduated test-tube and the volume of fluid displaced was taken as the volume of the epididymis. The caudal epididymis and the $5 \mathrm{ml}$ formalsaline were then poured into a mortar and homogenized into a suspension from which the sperm count was carried out using the improved Neubauerhaemocytometer under the microscope ${ }^{13}$.

Histological Examination: After removing the testes, they immediately fixed in Bouin's fluid for 12 hours and the Bouin's fixative washed from samples with $70 \%$ alcohol. the tissues were dehydrated progressively in ascending ethanol concentration then treated with xylene and embedded in paraffin. Five microns thick section of paraffin embedded tissues were mounted on glass slide and stained with heamatoxylin and eosin stain. Sections were examined by mean of light microscope. The sections were made from the middle portion of the testis and the component and functional changes for tissue of testis slide were examined by using light microscope ${ }^{14}$.

Statistical Analysis: The mean and standard deviation (mean $\pm \mathrm{SD}$ ) were calculated for all values. comparison between the control and the treated group. were done using the student's t-test. Difference were considered statistically significant at $(\mathrm{P} \leq 0.05)^{15}$.

\section{Result}

Effect of ethanolicextract of Anethumgraveolenson motility, live-dead sperm ratio and Sperm abnormalities in male rabbits: The obtained results in table (1) revealed a significant low $(\mathrm{P} \leq 0.05)$ in motility and live- dead sperm ratio in semen of male rabbits 
treated with ethanolic extract of Anethumgraveolens compared with control group, Moreover, there is a significant increase $(\mathrm{P} \leq 0.05)$ in abnormal sperm morphology of treated group as compared with control group.

Table (1): Effect of alcoholic extract of Anethumgraveolens on motility and live-dead sperm and sperm abnormalities in male rabbits

\begin{tabular}{|c|c|c|}
\hline Parameters & Control group & Treatment group \\
\hline Motility \% Sperm & $90.33 \pm 1.032 \mathrm{a}$ & $54.83 \pm 0.752 \mathrm{~b}$ \\
\hline Live-dead sperm ratio & $84.50 \pm 0.836 \mathrm{a}$ & $21.00 \pm 1.264 \mathrm{~b}$ \\
\hline Sperm abnormalities \% & $2.581 \pm 16.33 \mathrm{~b}$ & $28.83 \pm 1.471 \mathrm{a}$ \\
\hline
\end{tabular}

Values are expressed as mean \pm SD of 6 rabbit in each group. Means bearing different letters differ significantly $(\mathrm{P} \leq 0.05)$.

Effect of ethanolic extract of Anethumgraveolens on LH, FSH, Testosterone level in semen male rabbits: The mean values of $\mathrm{LH}, \mathrm{FSH}$, Testosterone concentration as presented in table (2), the results indicated a significant $(\mathrm{P} \leq 0.05)$ decline in serum above hormones of treated group with ethanolic extract of Anethumgraveolens compared with control group.

Table (2): Effect of alcoholic extract of Anethumgraveolens on LH, FSH and testosterone level in male rabbits

\begin{tabular}{|l|c|c|}
\hline Parameters & Control & Treatment \\
\hline LH $(\mathrm{m} \mathrm{IU} / \mathrm{ml})$ & $2.90 \pm 0.24 \mathrm{a}$ & $1.63 \pm 0.17 \mathrm{~b}$ \\
\hline FSH $(\mathrm{m} \mathrm{IU} / \mathrm{ml})$ & $1.73 \pm 0.15 \mathrm{a}$ & $0.71 \pm 0.16 \mathrm{~b}$ \\
\hline Testosterone $(\mathrm{ng} / \mathrm{ml})$ & $2.53 \pm 0.16 \mathrm{a}$ & $1.70 \pm 0.14 \mathrm{~b}$ \\
\hline
\end{tabular}

Values are expressed as mean $\pm \mathrm{SD}$ of 6 rabbit in each group. Means bearing different letters differ significantly $(\mathrm{P} \leq 0.05)$.

Sperm examination: In the control group the sperm was normal Fig. $(1, a)$, but sperms of rabbit treated with ethanolic extract of Anethumgraveolens showing large number of dead, and large number of different types of abnormal sperms were observed, coiled tail fig.(1,b), big head fig. $(1, c)$ headless tail fig. $(1, d)$ and tailless head fig. $(1, e)$.
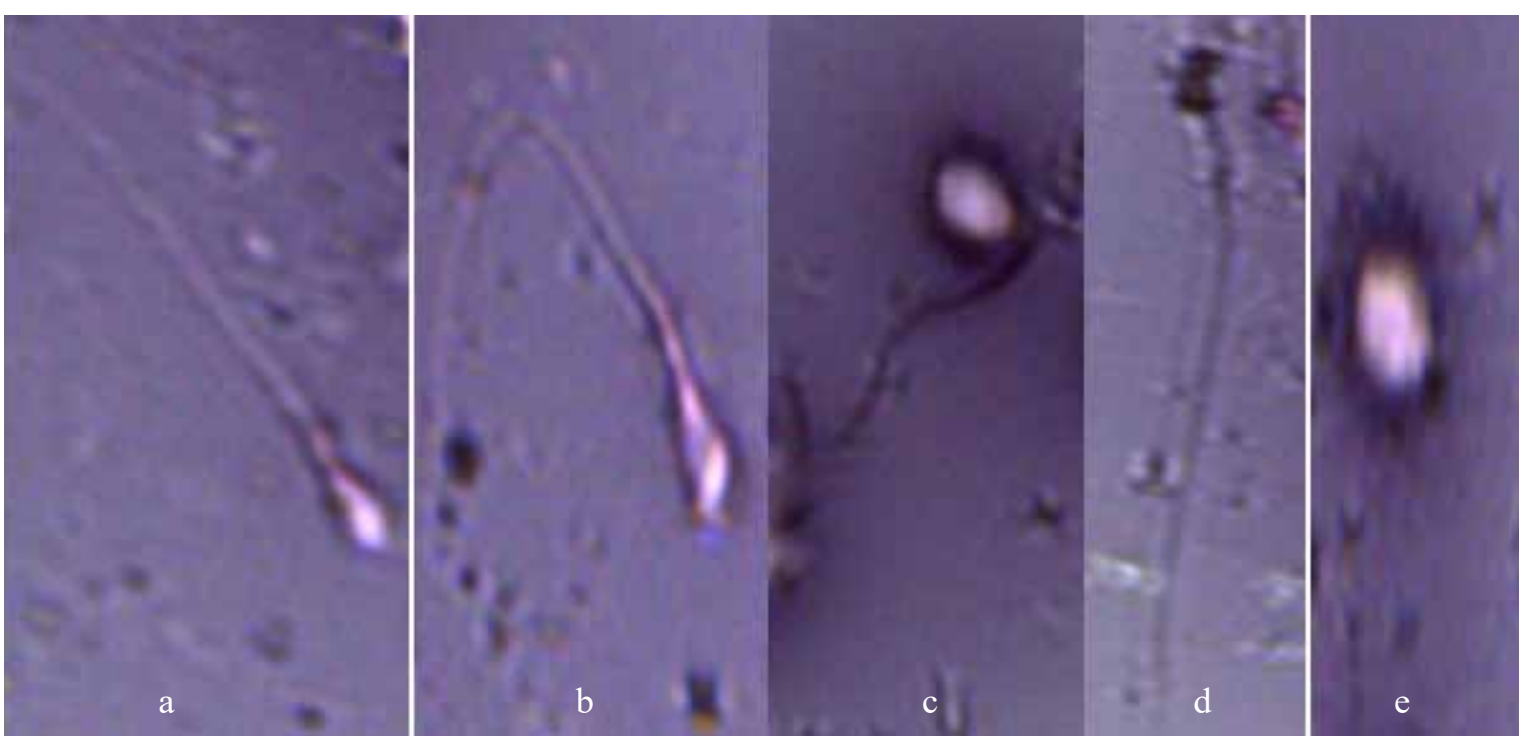

Figure 1: (a) Normal sperm in control group, various sperm defects (b-e) were observed. b: coiled tail, c: big head, d: headless tail and e: tailless head in treated group with ethanolic extract of Anethumgraveolens. 
Histological Examination: Section of testis of rabbit in control group showing normal seminiferous tubules and spermatogenesis (fig. 2), while section of testis of rabbit treated with ethanolic extract of Anethumgraveolens showing vacuolation of epithelial cells lining of seminiferous tubules (sertoli cells) with suppression of spermatogenesis, congested blood vessels, thickening in capsules, odema and fibrosis in interstitial tissue with inflammatory cells, degeneration of basement membrane and fragment of nucleolus cells (fig. 3).

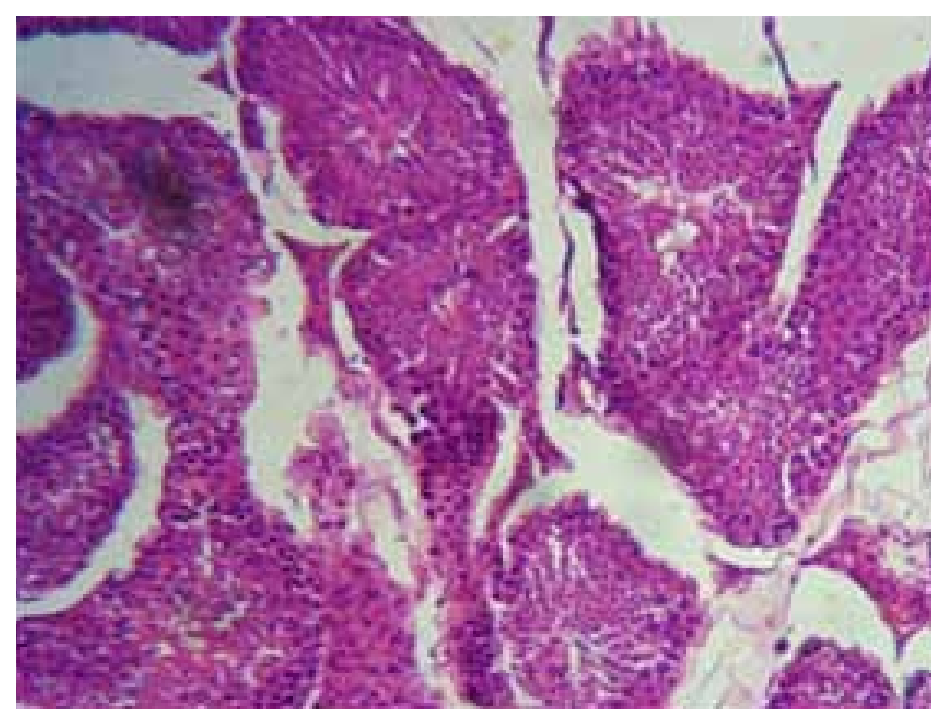

Fig. (2): Section of testis of rabbit (control), showing normal seminiferous tubules and spermatogenesis.

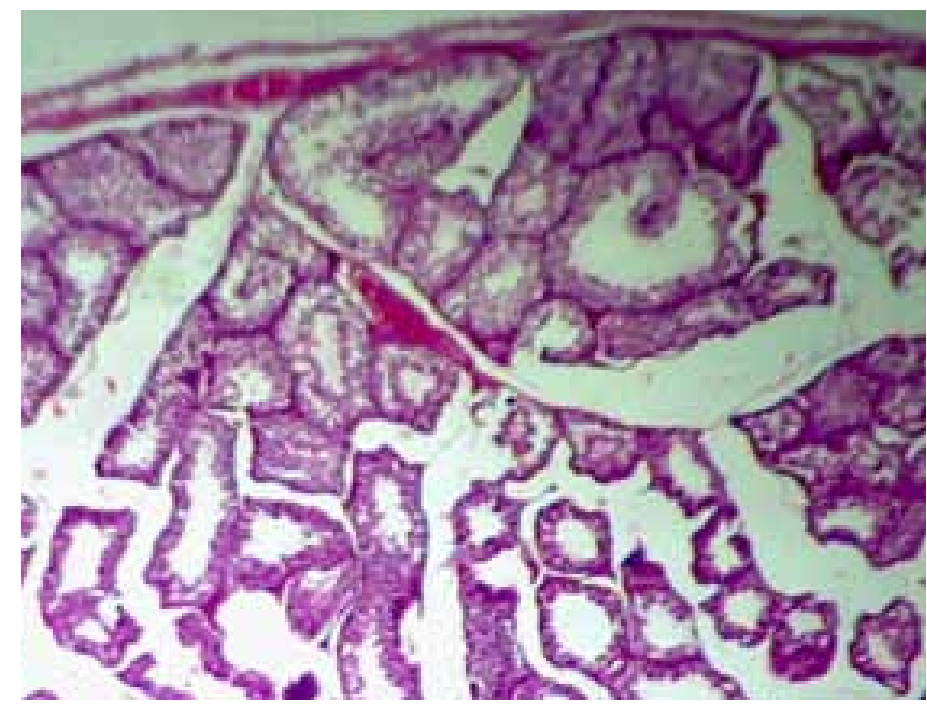

Fig (3): Section of testis of rabbit treated with extract, showing vacuolation of epithelial cells lining of seminiferous tubules ( ), congested blood vessels (C) with suppression of spermatogenesis and thicken in capsules $(T)$.

\section{Discussion}

In this study, Male rabbits administered ethanolic extract of Anethumgraveolens has significant decrease $(\mathrm{P} \leq 0.05)$ in sperm motility, live/dead and total sperm count when compared to the control group, which could be due to the effect of this extract on the cell cycle, cell division and expression of genes necessary for the spermatogenesis. It is also possible that these changes might be as a result of changes in the microenvironment of epididymis and creation of a toxic microenvironment presence in extract, thus influencing sperm count and motility ${ }^{16}$. 
In our study showed a significant decrease in the level of FSH and LH and testosterone concentrations in rabbits treated with ethanolic extract of Anethumgraveolensas compared with control group, this indicates that the active ingredients of the extract may alter the pituitary gonadotropins hormones like FSH and $\mathrm{LH}^{17}$, low levels of these hormones decrease endogenous testosterone secretion from the testis depriving developing sperm of the signal required for normal maturation and also it suppress testicular steroidogenesis and spermatogenesis ${ }^{17}$ since the pituitary-testicular axis is a central regulatory conduit for testicular function that culminates in the production of spermatozoa ${ }^{18}$.

Alteration of sperm cell morphology caused by Anethumgraveolens in our study, as a result of a fundamental problem with the process of maturation where abnormal sperm cells are matured from damaged seminiferous tubules ${ }^{19}$. Prolonged administration of the extract can be inferred to have harmful effects on the seminiferous tubules which is reflected in this study the high sperm cell abnormalities observed. this observation is supported by histopathological findings of the testes whereby rabbits administered with Anethumgraveolens exhibit varying degrees of lesions of the seminiferous tubules theses alterations might be caused by cytotoxicity of extract. This study demonstrated that the ethanolic extract of Anethumgraveolens have antifertility effect on testis of rabbits and could be further investigated for possibility of developing a cheap, acceptable and easy available male contraceptive.

Financial Disclosure: There is no financial disclosure.

Conflict of Interest: None to declare.

Ethical Clearance: All experimental protocols were approved under the College of Veterinary Medicine, and all experiments were carried out in accordance with approved guidelines.

\section{References}

1. Singh MP, Panda H. Medicinal Herbs with their Formulation. Daya Publishing House, Delhi, India. 2005.

2. Hosseinzadeh H, Karimi GR, Ameri, M. Effects of Anethumgraveolens L. Seed extracts on experimental gastric irritation models in mice. BMC Pharmacol. 2002; 2:1-5.

3. Naseri M, Mojab F, Khodadoost M. The study of anti-inflammatory activity of oil-based dill (Anethumgraveolens L.) extract used topically in formalin-induced inflammation male rat paw. Iranian Journal of Pharmaceutical Research.2012; 11(4):1169-1174.

4. Fleming T. PDR for Herbal Medicines. New Jersy: Medical Economics Company.2000; 252-253.

5. Delaquis P, Stanich K, Girard B, Mazza G. Antimicrobial activity of individual and mixed fractions of dill, cilantro, coriander and eucalyptus essential oils. Int. J. Food Microbiol. 2002; 74:101109.

6. Hajhashemi V, Abbasi N. Hypolipidemic activity of Anethumgraveolens in rats. Phytotherapy Research. 2008; 22(3):372-375.

7. Yazdanparast R, Alavi M. Antihyperlipidaemic and antihypercholesterolaemic effects of Anethumgraveolens leavesafter the removal of furocoumarins. Cytobios.2001; 105:185-191.

8. Nakano Y, Matsunaga H, Saita, T.Antiproliferative constituents in Umbelliferae plants II. Screening for polyacetylenes in some umbelliferae plants and isolation of panaxynol and falcarindiol from the root of heracleummoellendorffii. Biol. Pharm. Bull.1998; 21(3): 257-261.

9. Itarbone, J.B.(1998). Phytochemical method Aguidetomodern techniques. Kluwer Academic Publishers Imprint. Dordrecht. NI.

10. Mohammad-Reza P, Farzaneh D, Taherch TK, Zoherb P. The effect of hydroalcoholic extract of Actinidiachinensison sperm count and motility, and blood levels of estradiol and testosterone in male rats. Achieves of Iranian Medicine.2005; 8(3):211216.

11. Wyrobook A, Bruce W. Chemical induction of sperm abnormalities in mice. Pro. Nat. Acad. Sci.1975; 72: 4425-442.

12. Meistrich M, End V, Loris M. Temperature effect on the kinetics of spermatogenesis in the mouse. Cell tissue kinetic.1973; 6: $379-393$.

13. Sakamoto J, Hashimoto K. Reproductive toxicity of acrylamide and related compounds in mice effects on infertility and sperm morphology. Arch. Toxical.1986; 59: $201-205$.

14. Luna L. Manual of histology staining method of armed forces institute of pathology. 4th ed. Lange Medical printer. UK1993: 65-78. 
15. SPSS statistical packages for the social sciences. Statistical software for windows version 13.0 Microsoft. SPSS. Chicago. IL. USA.2001

16. Parisa, S, Leyla V, Hamed S, Jasem, E. The effects of Anethumgraveolens L. seeds on the male reproductive functions and CREM gene expression in the testis of rat. Research journal of applied sciences, engineering and technology. 2014; 7(9): 1883-1886.

17. Kusemiju T, Osinubi A. Effect of aqueous extract of the bark of Carica papaya on the testicular histology in Sprague-Dawley rats. Nig. Qt. J. Hop Med. 2010; 20(3): 133-137.
18. Cheng CY, Wong E, Yan HH, Mruk, DD. Regulation of spermatogenesis in the microenvironment of the seminiferous epithelium: new insights and advances. Mol. Cell Endocrinol. 2010; 315(12):49-56.

19. Thomas MJ, Thomas JA. Toxic responses of the reproductive system. In: Casarett \& Doull's Toxicology. The basic science of poisons ( $6^{\text {th }} \mathrm{ed}$.), McGraw-Hill Medical Publishing Division, New York. 2001; 677-681. 